CESIS Electronic Working Paper Series

Paper No. 387

\title{
Innovation and credit constraints: Evidence from Swedish
} exporting firms

\author{
Hans Lööf \\ Pardis Nabavi
}

December, 2014 


\title{
Innovation and credit constraints: Evidence from Swedish exporting firms*
}

\author{
Hans Lööf ${ }^{\dagger}$ and Pardis Nabavi $i^{\ddagger}$
}

\begin{abstract}
Using data from approximately 8,300, primarily small, exporting firms in Sweden observed over the business cycle period 1997-2007, we examine the relationship between innovation and financial factors in a regression that include changes in cash holdings, cash flow and debt issues. Our nonlinear econometric approach with interaction variables between recession period, technology intensity and finance suggests that innovative firms in high-tech sectors tend to offset the effect of a negative financial shock by exploiting internal cash resources. No corresponding link between innovation and financial factors is found for medium and low technology exporters.
\end{abstract}

JEL classifications: F14, G32, O16, O30, O32

Keywords: innovation, exports, credit constraints, non-linear panel data

${ }^{*}$ We are grateful for the helpful comments we received from the participants of CONCORDi-2013 conference and EARIE 2014 conference and three anonymous referees and the quest editors. The comments substantially improved the paper.

${ }^{\dagger}$ Department of Industrial Economics and Management, Royal Institute of Technology Lindstedtsvägen 30, 100-44 Stockholm; hans.loof@indek.kth.se; Corresponding author

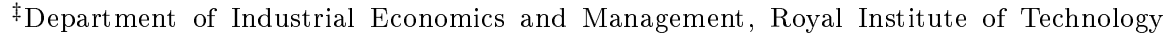
Lindstedtsvägen 30, 100-44 Stockholm; pardis.nabavi@indek.kth.se 


\section{Introduction}

Beginning with seminal papers by Hall (1992), and Himmelberg and Petersen (1994) a growing body of empirical literature examine the link between innovation and financial constraints at the firm level. It is now widely believed that a transitory finance shock may hit a firm's innovative activities differently depending on factors like size, age, and industry. In particular, small, young and high-tech firms have been found to be more sensitive to economic volatility (Hall, 2002).

Over the last decade, a number of micro econometric studies (Bellone et al., 2010; Minetti and Zhu, 2011; Egger and Kesinay, 2013; Gorg and Spaliara, 2013) have considered exports and financial constraints. Summarizing this literature, Wagner (2014), reports that exporting firms are less financially constrained than non-exporting firms. Since exporting is associated with higher fixed costs than serving the domestic market only, a self-selected group of superior firms with higher productivity, larger size and more innovations are more likely to be exporters than other firms (Bernard and Jensen, 1999).

Exporters may have greater possibilities to offset the consequences of financial shocks on innovation through various management strategies, including product and market diversification and greater amounts of customer-financed R\&D (Shaver, 2011). However, exporters are heterogeneous. Our data covering all manufacturing firms in Sweden with 10 or more employees and at least one export product over the period 1997-2007, shows that the typical exporter is not a large innovative firm operating across many destinations with a broad portfolio of products. The median exporter is a small firm with 26 employees, 6 export products, and participates in 6 foreign markets.

In this paper, we try to incorporate innovation into the literature on exports and credit constraints. While considerable progress has been made recently in 
our understanding of innovation and financial constraints, as well as in our understanding of the relationship between exports and financial constraints, the evidence base for financial constraints among innovative exporters remains limited. This is to some extent surprising given (i) the broad awareness of the relationship between increasing globalization of markets and the importance of exports competitiveness, and (ii) the considerable empirical literature suggesting a positive link between innovation and exporting (Love and Roper, 2015). Considering SMEs, a recent European survey of 9,480 firms in 33 countries, show that internationally active firms grow more than twice as fast as those active only in domestic market. Moreover, they are three times more likely to introduce products or services that are new to their sector than those which are entirely domestic in orientation (European Commission, 2010).

As with other studies of finance and innovation, we typically cannot observe whether innovative exporting firms operate under financial constraints or not. Based on different methodological approaches, some studies suggest financial problem for particular categories of R\&D engaged exporters. Ughetto (2008) finds that small firms face problem in accessing external finance for innovation and exports. Riding et al. (2012) suggest that the mix of uncertainty and commercial and technical risk in the early stages of exploration of foreign market potential may be associated with financing problems.

The period we study is a business cycle including the economic boom of the late 1990s, and the downturn related to the burst of the IT-bubble in the early 2000s and the following recovery period. The total number of unique firms in the study is about 8,300, of which only approximately 300 are publicly traded. In order to take into account the heterogeneity among exporters, we distinguish between different $R \& D$ intensities across four broad manufacturing sectors, as well as between persistent and temporary exporters. The covariates 
in the empirical analysis include firm size, human capital, physical capital, age and corporate ownership.

Exporting manufacturing firms are responsible for about $95 \%$ of private sector R\&D spending in Sweden. Unfortunately, the official Swedish business register does not collect annual statistics on $R \& D$ activity from firms with fewer than 250 employees. We have therefore chosen patent applications as our primary innovation indicator, since this measures is available for all filing firms in Sweden by merging the EPO-data base PATSTAT with the business register. Prior studies report that patent filings and $R \& D$ tend to move in parallel, although patenting is more closely correlated with the business cycle than $R \& D$ investments (OECD, 2009). The reason is that patent filings are a more controllable and flexible expense than R\&D, with its high adjustment costs. Although patent applications, as well as granted patents have a number of well-known shortcomings as innovation indicators, they have attracted much attention from researchers mainly due to the fact that patent so far is the only source of standardized information on new technologies collected systematically over a long period of time.

Our second innovation proxy is new export products. Export statistics come from Swedish Customs, and the data is based on the European Combined Nomenclature $(\mathrm{CN})$ system, established to meet the requirements both of the Common Customs Tariff and of the external trade statistics of the European Union. The standard permits to distinguish new export products from existing export products. However, a new export product may not necessarily be new for either the company or the domestic market. Regardless of how genuinely new the product is, market introduction involves a number of extra costs which can be quite substantial. Hall and Sena (2014) report that marketing expenditures are equivalent to $12 \%$ to $14 \%$ of innovation expenditures among small and 
large firms observed in the U.K Community Innovation Survey. Most likely, the cost is highest for the launch of new products in international markets. Wagner (2014) lists different expenditures that could be linked to product introduction in foreign markets, including acquisition of information about the target market, adoption of products to foreign legal rules or local tastes, instruction manuals in foreign languages, and setting up distribution networks.

To test the impact of internal and external equity finance on investment, a number of recent studies apply alternative versions of the Bond and Meghir (1994) structural approach that captures the influence of current expectations of future profitability on current investment decisions. Financial constraints are commonly captured by cash flow sensitivity in an investment function with physical capital as the dependent variable. Most recently, similar approaches have been employed to examine the importance of financial factors on $R \& D$ investments, with the hypotheses that constrained firms should have a positive cash flow sensitivity and negative relationship between $R \& D$ and growth in cash holdings, while unconstrained $R \& D$ investments should not be systematically related to internal financial factors.

This latter approach is the one we apply here, but with alternative proxies for innovation activities. The econometric method is a negative binomial estimator with interaction variables between recession period, technology intensity, and financial factors, while controlling for other co-determinants and unobserved heterogeneity. We confront the interaction variables with our two innovation indicators and test the relationship between innovation and financial factors. Our empirical analysis is applied across four broad manufacturing sector categories; high, high-medium, low-medium, and low technology, which follows the OECDs classification of manufacturing industries based on R\&D intensities.

Results of our non-linear econometric approach with patent filings as the 
dependent variable suggest that firms in high-tech sectors are more likely than other exporters to be financially distressed, and tend to use both cash flow and cash holdings to reduce the effect of a finance shock. No statistical significant link is found between new export products and a firm's management of liquidity.

In the remainder of this paper we briefly review the relevant literature (section 2), explain our data (section 3), introduce the methodological approach (section 4), provide results and analysis (section 5), and summarize (section 6).

\section{Innovation and financial shocks}

Due to capital-market imperfections most firms face financing problems in economic downturns. The problems are assumed to be more severe for $\mathrm{R} \& \mathrm{D}-$ investments due to limited collateral value and information asymmetry (Hall and Lerner, 2010). There is a general agreement within the literature that a negative finance shock should restrict innovative activities more in firms that are credit constrained, and it is commonly explained as follows: When a firm is hit by a negative shock, its current earnings are reduced, and therefore its ability to finance innovation investments is also reduced.

For firms forced to lay off researcher and development personnel in response to a transitory finance shock, the effect can be a costly erosion and obsolescence of acquired skills, routines and technology. Because of expensive adjustment costs, firms are assumed to be willing to free financial resources in order to offset transitory finance shocks and maintain a consistent innovation profile (Hall, 1992, 2002; Fazzari et al., 2000; Brown et al., 2012).

In this paper, we focus on the link between financial factors and innovation among exporting firms. Most of the existing literature on financial constraints and exports examines various ex-ante and ex-post issues. Two common themes are the effect of liquidity constraints on entry into export markets (Chaney, 
2013; Bellone et al., 2010), and the impact of participation in export markets on a firm's financial health (Campa and Shaver, 2002). Some recent studies suggest that exporting firms may be less vulnerable to financial distress since they are able to reduce exposure to demand-side shocks through diversification (Greenaway et al., 2007; Bellone et al., 2010).

A still limited number of studies incorporate innovation in their analyses of financial frictions among firms with foreign customers. Testing the hypothesis that $R \& D$ and exporting activities share some features that make them likely to suffer from shortage of finance, Manez et al. (2014) find that financial constraints are relevant for both the decision to export and to engage in $R \& D$.

The literature of innovation has long been studied characteristics that differentiate supply and demand driven R\&D. This aspect has also attracted attention from researchers investigating the conditions for financing intangible investments with limited collateral value, uncertain outcome and information problems. Recent literature argues that supply-driven generation of new knowledge tend to be relatively long-term, costly, and associated with high adjustment costs. In contrast, demand-driven $\mathrm{R} \& \mathrm{D}$ is mainly characterized as short-term, less expensive, and with low adjustment costs (Cantwell and Mudambi, 2005; Aghion et al., 2012).

There is anecdotical evidence that demand-driven and collaborative research and development projects are more likely to receive external co-funding from customers. Consider for instance Saab, which is one of Sweden's most R\&D intensive companies. They operate in the global market for defense and security solutions and develop systems with broad-based military and civil applications. In their official strategy for R\&D financing, the company states that: "Our dependency on customer-financed $\mathrm{R} \& \mathrm{D}$ is a challenge. Around two-thirds of customer financing currently comes from Sweden. Our growth opportunities are 
primarily in other countries, including selected markets where we are working to increase customer financing." (SAAB Annual Report, 2010).

The opportunity for product and market diversification, as well as the possibility of co-financing with international customers, could imply that innovative exporters are less vulnerable to financial shocks. In addition, there is an extensive literature showing that exporters are the result of a self-selection process, where the most productive and innovative firms are more likely to also operate in the international markets (Roper and Love, 2002; Basile, 2001; Pla-Barber and Alegre, 2007; Serti and Tomasi, 2008; Alvarez and López, 2005).

A number of arguments support the view that exporting companies would be less cyclically sensitive in their innovation activities than other companies. However, exporters are a heterogeneous group of firms (Secchi et al., 2014). Many exporting firms are small, have a limited product portfolio, and operate in only a few markets. Moreover a substantial fraction of firms don't have long-term customer contracts with the potential for co-funding of innovation projects.

Prior research on financial constraints and innovation have applied cash flow sensitivity in an investment function with $R \& D$ as the dependent variable. Several recent studies have demonstrated that the $R \& D$ cash flow sensitivity is an imperfect and weak indicator for detecting financing constraints and $R \& D$ smoothing. Alternative proxies should be used, as additional regressors, such as the change in cash reserves (Brown and Petersen, 2011), the use of external equity finance (Brown, Martinsson, and Petersen, 2012), the cash inflows from fixed asset sales (Borisova and Brown, 2013), and other proxies.

Our main conclusions from this brief literature review, is that we should apply more financial variables than cash flow for testing the existence of financial constraint among Swedish export companies and their attempts to reduce 
the negative effect by economic recession period by using internal financial reserves. There are arguments supporting the hypothesis that exporters are relatively robust against cyclical volatility across the business cycle (diversification of products and markets, financing with customers of long-term demand-driven projects). But there are also counter-arguments. Many exporting companies are small, they have few export products and export to only a few countries. In addition, supply-driven high-tech production might be more sensitive to macroeconomic fluctuations.

\section{Data description}

\subsection{Data sample}

The data set in this study is assembled from several different sources. First, register information from the audited annual accounts of all firms in Sweden between 1997-2007 is provided by Statistics Sweden (SCB). Second, trade statistics for all manufacturing firms in Sweden over the same period is provided by Swedish Customs and SCB. Finally, patent statistics is from the EPO Worldwide Statistical Database (PATSTAT) and supplemented by national data from the Swedish Patent Office.

The choice of period is motivated business cycle characteristics, with a boom period between 1997-2000, a bust period in connection with the ICT sector's "dot com bubble", and a recovery period that started in the second half of 2003. In the analysis we define the period 2001-2003 as "recession period", which is based on the statistics of Swedish goods exports between 1997-2007 provided by National Institute of Economic Research, Sweden.

To have the highest possible quality of the patent statistics, we have imposed a lower censoring limit of 10 employees for the observed firms. The Swedish ex- 
port statistics lacks systematic coverage of the smallest firms. The size limit is also relevant for the quality of our patent data. In total there was 198,354 patent applications from firms in Sweden over the period 1997-2007. In the matching process conducted by Statistics Sweden, more than $75 \%$ of these applications were linked with a unique firm in the Swedish business register. According to SCB, the remaining applications concern almost only firms with limited economic activities and therefore very few alternative matching variables. Likely the matching problem is mainly attributed to the smallest firms with few or no employees. Approximately $15 \%$ of the exporting firms applied for at least one patent during the sample period, and $40 \%$ of the firms introduced at least one new export product on the market. The corresponding figures for persistent exporting firms are $23 \%$ and $64 \%$, respectively.

In order to be included in the sample, a firm must have exported during at least one year over the study period. As a result, we end up with an unbalanced panel of 8,300 unique firms, one third of which $(2,713)$ are defined as persistent exporters since they reported positive exports across all years.

In all European countries, import and export goods are registered based the Combined Nomenclature (CN) system. The system was established to meet the requirements both of the Common Customs Tariff and of the external trade statistics of the European Union. In the paper we have exploited information from the $\mathrm{CN}$ register to track individual export products for individual firms in Sweden. To define an export product as new, we examine whether it has a new unique product code in the trade statistics year $t$, and that this unique code did not exist in period $t$-n. A drawback with this method, however is that a products identified as new for the export market does not necessarily need be new to the domestic market. 


\subsection{Summary statistics}

Table 1 presents descriptive statistics for all exporting firms and persistent exporters. Our main variables of interest are patent applications for each firm in each year and number of new export products which each firm create in each year. While there is an extensive literature that provides theoretical and empirical support for patents as an innovation indicator (with pros and cons), there is a lack of a corresponding scientific underpinnings for export products. This may be due to the availability of systematic data on new export products being a relatively new phenomenon. But there are also some methodological problems with this indicator, however, which to some extent are common with the widely used indicator "new products" in the Community Innovation Survey. Cash flow is defined as operating profit, minus taxes, plus depreciation and amortization, plus investments in plants and equipment. It should be noted that cash flow can be defined and measured in various ways. The definition used in our paper capture a firm's operating margins, while a more narrow measure is bank deposit, which is something that can be easily sold to meet credit obligation is change in cash and short-term investments. $\triangle$ Cash Hold is change in cash and short-term investments. SalesGrowth is the firms' growth in net sales. Firms' DebtGrowth is change in long term debt and all of these measures are divided by the total assets in beginning of the period. We measure size as $\log$ values of total number of employees. We also have an ownership indicator, which distinguishes between non-affiliate firms, members of domestic groups, domestic multinational groups, and members of foreign multinational groups. Following OECD-suggested classifications, we separate manufacturing firms into four broad sectors based on R\&D and human capital intensity: high, medium-high, medium-low, and low technology.

While similar patterns can be found amongst persistent exporters and the 
entire data set of firms, we can see persistent exporters are on average more innovative, have more employees, have higher physical capital intensity, and a somewhat higher proportion of skilled employees. Appendix A provides a definition of the variables in our analysis. Table B.1 in the Appendix B reports crosscorrelation statistics for the period 1997-2007. The most notable correlation reported is the one between contemporaneous and delayed patent applications (0.972). The corresponding correlation coefficient for export products is 0.176.

\section{Empirical Approach}

The central question in our paper is to test whether there is heterogeneity in the relationship between innovation and finance across exporters in high tech manufacturing and other manufacturing exporters. Methodologically our study has similarities with Brown and Petersen (2011), who examine the possibility to protect $R \& D$ investment from negative finance shocks among incorporated manufacturing firms in the U.S. The authors hypothesize that firms likely to face financing frictions should have incentives to build and manage a cash reserve in order to maintain relatively consistent annual $\mathrm{R} \& \mathrm{D}$ spending. In their empirical test, Brown and Petersen (2011) focus on changes in cash holdings in a regression that includes cash flow, debt issues, and stock issues. The theoretical prediction is that financially constraint firms should have a positive coefficient on cash flow and stock issues and a negative coefficient on cash holdings. The reason for the negative effect on cash holding is that reduction in cash holdings release cash for innovation activities, while an increase in cash flow and stock issues has the same effect. Financing through new long-term debt issues are assumed to be less relevant for most firms.

To test the impact of internal and external equity finance on investment, a number of studies apply a version of the Bond and Meghir (1994) structural ap- 
proach that captures the influence of current expectations of future profitability on current investment decisions. A major advantage of this dynamic optimization approach is that it is able to accommodate endogeneity through current and lagged financial variables, as well as a quadratic adjustment investment cost component. Since our dependent variable is not a continuous investment measure, but a count-data proxy for innovation, we are not able to use this attractive methodology.

Count data, such as patent applications, are often over-dispersed. Applying an over-dispersion test, suggested by Cameron and Trivedi (2005), we find that the null hypotheses on equality between mean and variance is violated for each of the two samples in our study. As a result, we consider the negative binomial regression method which accounts for over-dispersion. In order to improve the efficiency of the negative binomial estimator, we use the cluster-robust option for estimating the standard errors.

We specify the model as:

$$
\begin{aligned}
y_{j, t}= & \alpha_{1} y_{j, t-1}+\alpha_{2} \text { InSize }_{j, t}+\alpha_{3} \text { PhysicalCapital }_{j, t}+\alpha_{4} \text { HumanCapital }_{j, t} \\
& +\alpha_{5} \triangle \text { Sales }_{j, t}+\alpha_{6} \text { CashFlow }_{j, t} * \text { HighTech }_{j, t} * \text { Bust }_{t} \\
& +\alpha_{7} \text { CashFlow }_{j, t-1} * \text { HighTech }_{j, t} * \text { Bust }_{t} \\
& +\alpha_{8} \triangle \text { CashHold }_{j, t} * \text { HighTech }_{j, t} * \text { Bust }_{t} \\
& +\alpha_{9} \triangle \text { CashHold }_{j, t-1} * \text { HighTech }_{j, t} * \text { Bust }_{t}+\alpha_{10} \triangle \text { Debt }_{t} \\
& +\alpha_{11} \triangle \text { Debt }_{t-1}+\alpha_{12} \text { Age }_{j, t}+\text { Sector }_{j, t}+\text { Own }_{j, t}+d_{t}+\mu_{j}+\nu_{j, t}
\end{aligned}
$$

where $y$ is either the number of patent applications or new export products for firm $j$ in year $t$, lnSize is the logarithm of firm number of employees as a control for firm size, PhysicalCapital is the logarithm of physical capital, HumanCapital is human capital measured as the fraction of the employees with 
at least three year of university education, $\triangle$ Sales is sales growth which control for demand for innovation, Cash Flow is firm cash flow used as a proxy of access to internal finance rather than a sign of high firm demand (Brown and Petersen (2009)), $\triangle$ CashHold is growth of cash holdings, $\triangle D e b t$ is growth of long-term debt, Age is firm age, Sector is industry sector (high, high-medium, low medium and low technology), Own is corporate ownership structure (independent, uni national, domestic multinational, and foreign multinational), $d_{t}$ is a time specific effect included to control for aggregate changes that could affect the demand for innovation, $\mu_{j}$ is firm specific fixed effect, and $\nu_{j, t}$ is the idiosyncratic error term. Equation (1) includes interaction between the Cash Flow and $\triangle$ CashHold with High Tech manufacturing firms and recession period (Bust). Cash-flow, cash holding, sales, long-term debts are all normalized by total assets in period $t-1$. We expect to find a positive relation between cash flow and innovation for firms facing financing constraints, while growth of cash holdings is assumed to be negative for financially constrained firms. Prior studies suggest that equity finance should be the principal source of fund for innovation investments, while debt financing is associated with several problems (?Hall, 2002). We therefore do not assume any strong link between change in long-term debt and innovation.

It should be noted that since the lagged dependent variables appear as explanatory variables, strict exogeneity of the regressors no longer holds (Nickell, 1981). There are several possible solutions to potential endogeneity problems in our estimations, and in a sensitivity analysis we provide different test of the robustness of the negative binomial results. Regarding the results presented in the next section, we assume that a potential endogeneity problem should not be biased towards one of the two groups that we compare. 


\section{$5 \quad$ Results}

In the empirical analysis, we consider potential liquidity constraints among exporting firms and we test whether the link between innovation and financial factors differs across firms depending on their technology intensity. The estimations apply two different proxies for innovation; the first is patent applications, and we assume that they are related to the early phase in firms' innovation process while new export products are considered to be a proxy for innovation activities in final stage of the process. The results for patents are presented in Table 2 and the corresponding results for export products are presented in Table 3. The left column of both tables reports coefficient estimates for all 8,300 observations, while the right column shows the corresponding figures for the persistent exporters subgroup.

We estimate the model by negative binomial regression. In all equations, we control for size, physical capital, human capital, age, sales growth, debt growth, technology intensity (sector), ownership (non-affiliate, domestic uni national, domestic multinational, and foreign multinational) and year. In order to save space, our analysis focuses on the eight cash-flow-variables and the eight cash-hold variables, all interacted with industry sector (high-technology or not) and business cycle period (recession or not). The co-variates show expected results: Innovation is positively correlated with firm size, and human capital, and technology intensity. The bottom of both tables report the Vuong test which indicate that the standard negative binomial is the appropriate model. Importantly, the lower part of the tables also reports the critical $c h i^{2}$ test statistics for the sum of instantaneous and lagged coefficient estimates. Our main analysis deals with these results.

Consider first Table 2 and the patent-specification of equation (1). Our prediction for financially constrained firms is that the sum of the instantaneous 
and lagged cash flow variables should be positive and significant in the economic recession period 2001-2003 (Bust), while the sum of the cash-holding variables should be negative for this period. All else equal, increased cash flow and reductions on cash holding should free resources for firms' innovation activities. If the firms are not financially constrained, the sum of the two estimates should be close to zero.

A comparison of the cash-flow estimates for non high tech firms (NHT) and high tech firms (HT) in the bust period for all exporters (column 1), shows that the sum of contemporaneous and lagged NHT-coefficient is close to zero (-0.046) and non-significant, while the sum is substantial (0.727) and significant for HTfirms. The results are similar for the subgroup consisting of only persistent exporters. The sum of the two cash-flow coefficients is -0.063 (non-significant) for NHT-firms and 1.078 (significant) for HT firms in the recession period.

Results for the cash-holding variable is entirely consistent with the cash-flow estimates. We expect that financial friction is reflected in a negative growth of cash holding, and about zero otherwise. Column 1 (all exporters) reports positive estimates on both contemporaneous and lagged variables for NHT-firms and they are not significantly different from zero. Both estimates for HT-firms are negative as predicted (-0.006 and -0.445$)$ and just outside the $10 \%$ level of significance (the p-value is 0.14 ). The results for persistent exporters have the expected sign only for high-tech firms. The sum of the estimates is -0.233 , however, thechi $i^{2}$ test statistics cannot confirm that the estimates for the recession period are significant different from zero.

The broader result from Table 2 is that we see a clear difference between high-tech firms and others even if it cannot be fully confirmed by our significance tests. We find no evidence on financial friction among Swedish export companies in low and medium-tech industries, suggesting that this self-selected category 
of superior firms are able to smooth their innovation expenditures during less favorable times. However, there is evidence that high-tech firms are facing financial constraints. The sum of the two cash-flow estimates are positive and substantial in the boom period, 1.025 for all firms and 2.095 for persistent exporters, and switches to negative in the bust period.

Table 3 reports the relationship between new export products and financial factors. As discussed above, the introduction of a new export product does not necessarily mean that it is the result of a recent innovation process. It may also involve an existing product launched in a new market. However, this can also be costly in terms of marketing and other related expenses. The sum of the cashflow estimates are typically negative and non-significant, while the cash-holding estimates have the expected negative sign for both the contemporaneous and lagged variable only for persistent exporting firms. The sum of the coefficients is substantial (-0.389), however, not statistically different from zero.

Overall the results in Table 2 show a predicted positive relation between cash flow and innovation (patent), and a predicted negative relation between changes in cash holdings and innovation (patent) for high tech exporters during the recession period 2001-2003. The sum of the contemporaneous and lagged cash flow estimates are significantly different from zero for the whole sample of exporters as well as for the subgroup consisting only of persistently exporting firms. The sum of the cash-holding variables are substantial but non-significant in both samples, however close to the $10 \%$ significance level for the sample with all exporters. Moreover, high-tech firms tend to build cash reserves in good times. The sum of the estimates for the interaction variable $\triangle$ CashHold $\times$ $H T \times B o o m$ is positive and sizable in both the whole sample (1.025) and in the sub sample with persistent exporters (1.993). The relationship between new export products and cash flow reported in Table 3 is positive for both 
samples, but small in magnitude and non significant. The corresponding results for change in cash holding has the predicted negative sign only for persistent exporters, but we cannot reject the null hypothesis.

The summarizing finding from our study is that financially constrained innovative high-technology Swedish firms operating in international markets tend to use cash management as a cyclical controller to reduce the effect of the business cycle fluctuations. However, applying introduction of new products as a proxy for innovation, the results from the patent equation cannot be statistically confirmed, which might question whether a new export product should be considered as an innovation indicator. An alternative interpretation might be that the presence of financial constraints are more relevant for the early phase of the innovation process, compared to the late phase.

It is notable that our results reported in Table 2 are in line with Brown and Petersen (2011), despite several significant differences: (i) 95\% of the Swedish companies in our study are private, while they consider only publicly traded firms, (ii ) our data represents all exporting firms in Sweden with 10 or more employees and the median firms has less than 30 employees. The Compustat data used by Brown and Petersen is biased towards large firms, (iii) our preferred innovation indicator is the patent application while they use $R \& D$, and (iv) Brown and Petersen estimate a modified dynamic Euler equation with a two step GMM-approach, and we use a negative binomial panel data estimator.

To examine the sensitivity of our results to alternative estimation methods, we conduct several robustness tests using approaches supposed to account for potential endogeneity bias. The results show that the main findings are robust across the various approaches. 


\section{Conclusions}

This paper makes a distinction between indicators related to the early and final phases of the innovation process, and examines how financial factors influence investments related to patent applications and the introduction of new export products across industries and business cycles. Applying a non-linear panel data model on exporting manufacturing firms in Sweden, we find evidence of financial constraints only for high-technology firms, where the result is similar for all exporters and for the subgroup of persistent exporters. The results are valid only for patent applications (early phase), while no significant results could be found for product introduction.

Why is it important to know more about possible financial distress among exporters? Exports play a central role for employment, growth and welfare in all modern economies, and there is a wide array of economic policy tools to stimulate exports like reduced barriers to trade, export credits and governmental trade councils with localization in the regions considered as important for national exports.

There is a broad agreement in the literature that firms operating in international markets are self-selected into exports due to factors like size, productivity and innovation. Large exporting firms are also more able to offset consequences of financial shocks through management strategies, such as; product and destination diversification and co-financing innovation project with customers. However, our data covering mainly non-publicly traded firms shows that the typical exporter is not a large innovative firm operating across many destinations with a broad portfolio of products. Exporters are heterogeneous in most conceivable dimensions.

The economic importance of exports, the extensive heterogeneity among exporters, and the limited number of studies on the relationship between innova- 
tion and finance among this category of firms justifies our study. The existence of liquidity constraints in firms has considerable policy implications with regard to taxation, financial markets, employment, growth, and welfare. It is therefore important to determine whether a financial shock effects innovation investments in general or only a particular category of the exporters. To formally examine the finance-innovation link, we make use of a modified application of a method suggested by Brown and Petersen (2011). In the empirical approach, we observe potential financial constraints by cash-holding and cash-flow. Despite the difference in data and approach between our paper and the Brown and Petersen study, the main results are similar: innovative firms facing financing frictions appear to be able to partially offset a financial shock through cash reserves. 


\section{References}

Aghion, P., Askenazy, P., Berman, N., Cette, G., Eymard, L., Credit, L. E., 2012. Credit constraints and the cyclicality of R\&D investment: Evidence from France. Journal of the European Economic Association 10 (5), 1001-1024.

URL http: //onlinelibrary.wiley.com/doi/10.1111/j.1542-4774.2012.01093.x/full

Alvarez, R., López, R. a., 2005. Exporting and performance: Evidence from Chilean plants. Canadian Journal of Economics 38 (4), 1384-1400.

Basile, R., 2001. Export behaviour of Italian manufacturing firms over the nineties: the role of innovation. Research Policy 30 (8), 1185-1201.

URL http://www . sciencedirect.com/science/article/pii/S0048733300001414

Bellone, F., Musso, P., Nesta, L., Schiavo, S., 2010. Financial Constraints and Firm Export Behaviour. World Economy 33 (3), 347-373.

URL http://doi.wiley.com/10.1111/j.1467-9701.2010.01259.x

Bernard, A. B., Jensen, B. J., Feb. 1999. Exceptional exporter performance: cause, effect, or both? Journal of International Economics 47 (1), 1-25.

URL http://linkinghub.elsevier.com/retrieve/pii/S0022199698000270

Bond, S., Meghir, C., 1994. Dynamic Investment Models and the Firm's Financial Policy. The Review of Economic Studies 61 (2), 197-222.

Borisova, G., Brown, J. R., Jan. 2013. R\&D sensitivity to asset sale proceeds: New evidence on financing constraints and intangible investment. Journal of Banking \& Finance 37 (1), 159-173.

URL http://linkinghub.elsevier. com/retrieve/pii/S0378426612002610

Brown, J. R., Martinsson, G., Petersen, B. C., Nov. 2012. Do financing constraints matter for R\&D? European Economic Review 56 (8), 1512-1529.

URL http://linkinghub.elsevier.com/retrieve/pii/S0014292112001080

Brown, J. R., Petersen, B. C., 2009. Why has the investment-cash flow sensitivity declined so sharply? Rising R\&D and equity market developments. Journal of Banking \& Finance 33 (5), 971-984.

URL http://linkinghub.elsevier.com/retrieve/pii/S0378426608002550

Brown, J. R., Petersen, B. C., 2011. Cash holdings and R\&D smoothing. Journal of Corporate Finance 17 (3), 694-709.

URL http://linkinghub.elsevier.com/retrieve/pii/S0929119910000040

Cameron, A. C., Trivedi, P. K., 2005. Microeconometrics: Methods and Applications. Cambridge University Press, New York.

Campa, J., Shaver, J., 2002. Exporting and capital investment: On the strategic behavior of exporters. IESE Business School, University of Navarra, Reserch Paper No. 469. 
Cantwell, J., Mudambi, R., 2005. MNE competence-creating subsidiary mandates. Strategic Management Journal 26 (12), 1109-1128.

URL http://doi .wiley.com/10.1002/smj .497

Chaney, T., 2013. Liquidity constrained exporters. NBER Working paper No. 19170.

URL http://www .nber.org/papers/w19170

Egger, P., Kesinay, M., 2013. Financial constraints and exports: Evidence from chinese firms. CESifo Economic Studies 59, 676-706.

European Commission, 2010. Internationalisation of European SMEs. Brussels: Directorate-General for Enterprise and Industry. European Commission.

Fazzari, S. M., Hubbard, R. G., Petersen, B. C., 2000. Investment-cash flow sensitivities are useful: A comment on Kaplan and Zingales. Quarterly Journal of Economics 115 (2), 695-705.

URL http://ajae.oxf ordjournals .org/content/72/4/local/advertising.pdf

Gorg, H., Spaliara, M., 2013. Export Market Exit, Financial Pressure and the Crisis. CEPR Discussion Paper No. DP9599.

URL Available at SSRN: http://ssrn.com/abstract=2309243

Greenaway, D., Guariglia, A., Kneller, R., 2007. Financial factors and exporting decisions. Journal of International Economics 73 (2), 377-395.

URL http://linkinghub.elsevier.com/retrieve/pii/S0022199607000554

Hall, B. H., 1992. Investment and Research and Development at the Firm Level Does the Source of Financing Matter. NBER Working Paper 4096.

Hall, B. H., 2002. The Financing of Research and Development. NBER Working Paper No. 8773.

Hall, B. H., Lerner, J., 2010. The Financing of R \& D and Innovation. In: Hall, B. H., Rosenberg, N. (Eds.), Handbook of the Economics of Innovation. Elsevier-North Holland, North-Holland.

Hall, B. H., Sena, V., 2014. Appropriability Mechanisms, Innovation and Productivity: Evidence from the UK. NBER Working Paper No. 20514.

Himmelberg, C., Petersen, B., 1994. R \& D and internal finance: A panel study of small firms in high-tech industries. The Review of Economics and Statistics 76 (1), 38-51.

URL http://www .jstor .org/stable/2109824

Love, J. H., Roper, S., 2015. SME innovation, exporting and growth: A review of existing evidence. International Small Business Journal 33, 28-48.

URL http://isb.sagepub.com/cgi/doi/10.1177/0266242614550190 
Manez, J. a., Rochina-Barrachina, M. E., Sanchis-Llopis, J. a., Vicente, O., 2014. Financial constraints and R\&D and exporting strategies for Spanish manufacturing firms. Industrial and Corporate Change 23 (6), 1563-1594. URL http://icc .oxfordjournals.org/cgi/doi/10.1093/icc/dtu034

Minetti, R., Zhu, S. C., Mar. 2011. Credit constraints and firm export: Microeconomic evidence from Italy. Journal of International Economics 83 (2), 109-125.

URL http://linkinghub.elsevier.com/retrieve/pii/S0022199611000043

Nickell, S., 1981. Biases in dynamic models with fixed effects. Econometrica 49 (6), 1417-1426.

OECD, 2009. OECD Annual report 2009. Tech. rep.

Pla-Barber, J., Alegre, J., 2007. Analysing the link between export intensity, innovation and firm size in a science-based industry. International Business Review 16 (3), 275-293.

Riding, A., Orser, B. J., Spence, M., Belanger, B., 2012. Financing new venture exporters. Small Business Economics 38, 147-163.

Roper, S., Love, J. H., 2002. Innovation and export performance: evidence from the UK and German manufacturing plants. Research Policy 31 (7), 1087-1102. URL http://linkinghub.elsevier.com/retrieve/pii/S0048733301001755

SAAB Annual Report, 2010. "Security in a Changing World". Tech. rep.

Secchi, a., Tamagni, F., Tomasi, C., 2014. The micro patterns of export diversification under financial constraints. Industrial and Corporate Change 23 (6), $1595-1622$.

URL http://icc.oxfordjournals.org/cgi/doi/10.1093/icc/dtu036

Serti, F., Tomasi, C., 2008. Self-selection and post-entry effects of exports: Evidence from italian manufacturing firms. Review of World Economics 144, 660-694.

Shaver, J., 2011. The benefits of geographic sales diversification: How exporting facilitates capital investment. Strategic Management Journal 32, 1046-1060.

Ughetto, E., Apr. 2008. Does internal finance matter for R\&D? New evidence from a panel of Italian firms. Cambridge Journal of Economics 32 (6), 907-925. URL http://cje.oxfordjournals.org/cgi/doi/10.1093/cje/ben015

Wagner, J., 2014. Credit constraints and exports : Evidence for German manufacturing enterprises. Applied Economics 46 (3), 294-302. 


\section{$\begin{array}{ll}7 & \text { Tables }\end{array}$}

Table 1: Descriptive Statistics

\begin{tabular}{|c|c|c|c|c|c|c|}
\hline & \multicolumn{3}{|c|}{$\overline{\mathrm{All}}$} & \multicolumn{3}{|c|}{ Persistent } \\
\hline & mean & p50 & $\mathrm{sd}$ & mean & p50 & $\mathrm{sd}$ \\
\hline Patent $_{t}$ & 1.05 & 0.00 & 23.05 & 2.46 & 0.00 & 39.89 \\
\hline New Export $\operatorname{Prod}_{t}$ & 0.18 & 0.00 & 0.85 & 0.29 & 0.00 & 1.10 \\
\hline Size $_{t}, \log$ & 3.45 & 3.26 & 1.28 & 3.93 & 3.74 & 1.25 \\
\hline Physical Capital $_{t}$ & 14.54 & 14.81 & 3.18 & 15.46 & 15.44 & 2.39 \\
\hline Human Capital $_{t}$ & 0.07 & 0.03 & 0.12 & 0.08 & 0.05 & 0.10 \\
\hline Age $_{t}$ & 13.47 & 14.00 & 4.97 & 16.35 & 17.00 & 3.40 \\
\hline$\triangle$ Sales $_{t}$ & -0.03 & 0.00 & 0.81 & -0.00 & 0.00 & 0.65 \\
\hline Cash Flow $_{t}$ & 0.21 & 0.17 & 0.23 & 0.21 & 0.18 & 0.18 \\
\hline$\triangle$ CashHold $_{t}$ & -0.01 & -0.00 & 0.16 & -0.00 & -0.00 & 0.13 \\
\hline$\triangle \mathrm{Debt}_{t}$ & 0.02 & 0.00 & 0.21 & 0.01 & 0.00 & 0.17 \\
\hline High Tech & 0.07 & 0.00 & 0.26 & 0.08 & 0.00 & 0.27 \\
\hline High-Medium Tech & 0.27 & 0.00 & 0.44 & 0.33 & 0.00 & 0.47 \\
\hline Low-Medium Tech & 0.32 & 0.00 & 0.47 & 0.29 & 0.00 & 0.46 \\
\hline Low Tech & 0.34 & 0.00 & 0.47 & 0.30 & 0.00 & 0.46 \\
\hline Uni-National & 0.28 & 0.00 & 0.45 & 0.20 & 0.00 & 0.40 \\
\hline Domestic MNE & 0.30 & 0.00 & 0.46 & 0.27 & 0.00 & 0.45 \\
\hline Foreign MNE & 0.23 & 0.00 & 0.42 & 0.30 & 0.00 & 0.46 \\
\hline Independent & 0.15 & 0.00 & 0.36 & 0.20 & 0.00 & 0.40 \\
\hline Observations & 52,155 & & & 20,433 & & \\
\hline Uniqe firms & 8,300 & & & 2,713 & & \\
\hline
\end{tabular}


Table 2: Negative Bionomial, patent

\begin{tabular}{|c|c|c|c|c|}
\hline \multirow{3}{*}{$\frac{\text { Patent }_{t}}{\text { Patent }_{t-1}}$} & \multirow{2}{*}{\multicolumn{2}{|c|}{$\begin{array}{l}\text { (1) } \\
\text { All }\end{array}$}} & \multicolumn{2}{|c|}{$(2)$} \\
\hline & & & Persi & ent \\
\hline & $0.001^{* * *}$ & $(0.00)$ & $0.001^{* * *}$ & $(0.00)$ \\
\hline Size $_{t}, \log$ & $0.209^{* * *}$ & $(0.03)$ & $0.243^{* * *}$ & $(0.04)$ \\
\hline Physical Capital $_{t}$ & $0.091^{* * *}$ & $(0.01)$ & $0.039^{*}$ & $(0.02)$ \\
\hline Human Capital $_{t}$ & $2.326^{* * *}$ & $(0.17)$ & $1.840^{* * *}$ & $(0.28)$ \\
\hline Age $_{t}$ & -0.004 & $(0.01)$ & 0.012 & $(0.02)$ \\
\hline$\triangle$ Sales $_{t}$ & -0.048 & $(0.03)$ & -0.043 & $(0.04)$ \\
\hline 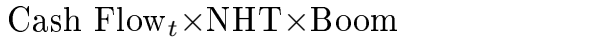 & $0.335^{*}$ & $(0.18)$ & 0.316 & $(0.25)$ \\
\hline Cash Flow $_{t-1} \times \mathrm{NHT} \times$ Boom & -0.072 & $(0.18)$ & 0.129 & $(0.25)$ \\
\hline Cash Flow $_{t} \times$ NHT $\times$ Bust & 0.071 & $(0.24)$ & -0.106 & $(0.31)$ \\
\hline${\text { Cash } \text { Flow }_{t-1} \times \mathrm{NHT} \times \text { Bust }}$ & -0.117 & $(0.22)$ & 0.043 & $(0.29)$ \\
\hline 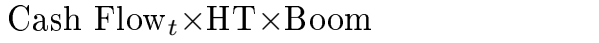 & 0.097 & $(0.31)$ & -0.045 & $(0.40)$ \\
\hline${\text { Cash } \text { Flow }_{t-1} \times \mathrm{HT} \times \text { Boom }}$ & 0.275 & $(0.30)$ & $0.971^{* *}$ & $(0.46)$ \\
\hline Cash Flow Fl $_{t} \times \mathrm{HT} \times$ Bust & 0.182 & $(0.37)$ & -0.066 & $(0.51)$ \\
\hline Cash Flow $_{t-1} \times \mathrm{HT} \times$ Bust & 0.545 & $(0.33)$ & $1.144^{* *}$ & $(0.45)$ \\
\hline$\triangle$ Cash Hold ${ }_{t} \times$ NHT $\times$ Boom & -0.208 & $(0.19)$ & 0.088 & $(0.28)$ \\
\hline$\triangle$ Cash Hold H-1 $\times$ NHT $\times$ Boom & -0.162 & $(0.19)$ & -0.235 & $(0.27)$ \\
\hline$\triangle$ Cash Hold ${ }_{t} \times \mathrm{NHT} \times$ Bust & 0.321 & $(0.28)$ & 0.066 & $(0.38)$ \\
\hline$\triangle{\text { Cash } \text { Hold }_{t-1} \times \mathrm{NHT} \times \text { Bust }}$ & 0.365 & $(0.27)$ & 0.025 & $(0.33)$ \\
\hline$\triangle$ Cash $\operatorname{Hold}_{t} \times \mathrm{HT} \times$ Boom & 0.484 & $(0.31)$ & 0.676 & $(0.43)$ \\
\hline$\triangle$ Cash Hold $_{t-1} \times \mathrm{HT} \times$ Boom & $0.541^{*}$ & $(0.33)$ & $1.419^{* * *}$ & $(0.51)$ \\
\hline$\triangle$ Cash Hold $\times$ HT $\times$ Bust & -0.006 & $(0.35)$ & 0.574 & $(0.52)$ \\
\hline$\triangle$ Cash Hold $_{t-1} \times \mathrm{HT} \times$ Bust & $-0.445^{*}$ & $(0.26)$ & $-0.807^{* *}$ & $(0.38)$ \\
\hline$\triangle$ Debt $_{t}$ & -0.108 & $(0.10)$ & -0.220 & $(0.14)$ \\
\hline$\triangle$ Debt $_{t-1}$ & -0.094 & $(0.11)$ & -0.180 & $(0.14)$ \\
\hline High Tech & $1.297^{* * *}$ & $(0.12)$ & $1.170^{* * *}$ & $(0.17)$ \\
\hline High-Medium Tech & $1.279^{* * *}$ & $(0.10)$ & $1.177^{* * *}$ & $(0.14)$ \\
\hline Low-Medium Tech & $0.902^{* * *}$ & $(0.10)$ & $0.960^{* * *}$ & $(0.14)$ \\
\hline Domestic MNE & 0.107 & $(0.11)$ & -0.152 & $(0.14)$ \\
\hline Foreign MNE & $0.796^{* * *}$ & $(0.10)$ & $0.476^{* * *}$ & $(0.13)$ \\
\hline Independent & $0.769^{* * *}$ & $(0.10)$ & $0.389^{* * *}$ & $(0.13)$ \\
\hline Voung test(p-value) & 0.49 & & 0.19 & \\
\hline sum CashFlow HT $\times$ Bust (p-value) & 0.02 & & 0.01 & \\
\hline sum CashFlow NHT $\times$ Bust (p-value) & 0.96 & & 0.99 & \\
\hline sum $\triangle$ CashHold $H T \times$ Bust (p-value) & 0.35 & & 0.74 & \\
\hline sum $\triangle$ CashHold $N H T \times$ Bust ( $p$-value) & 0.14 & & 0.88 & \\
\hline sum $\triangle \operatorname{Debt}(p$-value $)$ & 0.22 & & 0.07 & \\
\hline Observations & 52,155 & & 20,433 & \\
\hline Uniqe firms & 8,300 & & 2,713 & \\
\hline
\end{tabular}

Robust standard errors in parenthesis

${ }^{*} p<0.1,{ }^{* *} p<0.05,{ }^{* * *} p<0.01$ 
Table 3: Negative Bionomial, New export product

\begin{tabular}{|c|c|c|c|c|}
\hline \multirow{2}{*}{$\begin{array}{l}\text { New Export } \operatorname{Prod}_{t} \\
\text { New Export } \operatorname{Prod}_{t-1}\end{array}$} & \multicolumn{2}{|c|}{$\begin{array}{l}(1) \\
\text { All }\end{array}$} & \multicolumn{2}{|c|}{$\begin{array}{c}(2) \\
\text { Persistent }\end{array}$} \\
\hline & $0.019^{* *}$ & $(0.01)$ & 0.013 & $(0.01)$ \\
\hline Size $_{t}, \log$ & $0.415^{* * *}$ & $(0.02)$ & $0.368^{* * *}$ & $(0.03)$ \\
\hline Physical Capital $_{t}$ & 0.005 & $(0.01)$ & $-0.022^{*}$ & $(0.01)$ \\
\hline Human Capital ${ }_{t}$ & $0.457^{* * *}$ & $(0.14)$ & $0.877^{* * *}$ & $(0.20)$ \\
\hline $\mathrm{Age}_{t}$ & $0.012^{* * *}$ & $(0.00)$ & $-0.015^{*}$ & $(0.01)$ \\
\hline$\triangle$ Sales $_{t}$ & $-0.053^{* *}$ & $(0.02)$ & $-0.062^{*}$ & $(0.04)$ \\
\hline Cash Flow $_{t} \times$ NHT $\times$ Boom & 0.017 & $(0.12)$ & 0.266 & $(0.18)$ \\
\hline Cash Flow $_{t-1} \times \mathrm{NHT} \times$ Boom & $-0.201^{*}$ & $(0.12)$ & $-0.512^{* * *}$ & $(0.19)$ \\
\hline Cash Flow $_{t} \times$ NHT $\times$ Bust & $0.521^{* *}$ & $(0.25)$ & $0.655^{*}$ & $(0.35)$ \\
\hline Cash Flow $_{t-1} \times$ NHT $\times$ Bust & $-1.236^{* * *}$ & $(0.26)$ & $-1.875^{* * *}$ & $(0.38)$ \\
\hline 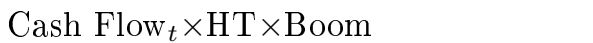 & 0.262 & $(0.26)$ & 0.449 & $(0.38)$ \\
\hline Cash Flow $_{t-1} \times \mathrm{HT} \times$ Boom & -0.293 & $(0.26)$ & -0.215 & $(0.41)$ \\
\hline Cash Flow $_{t} \times \mathrm{HT} \times$ Bust & 0.166 & $(0.52)$ & 0.384 & $(0.74)$ \\
\hline Cash Flow $_{t-1} \times \mathrm{HT} \times$ Bust & -0.121 & $(0.48)$ & -0.292 & $(0.69)$ \\
\hline$\triangle$ Cash Hold $_{t} \times \mathrm{NHT} \times$ Boom & 0.034 & $(0.14)$ & -0.202 & $(0.21)$ \\
\hline$\triangle$ Cash Hold $_{t-1} \times$ NHT $\times$ Boom & 0.067 & $(0.14)$ & 0.104 & $(0.21)$ \\
\hline$\triangle$ Cash Hold $_{t} \times \mathrm{NHT} \times$ Bust & $-0.622^{*}$ & $(0.33)$ & -0.764 & $(0.49)$ \\
\hline$\triangle$ Cash Hold $t_{-1} \times \mathrm{NHT} \times$ Bust & 0.441 & $(0.31)$ & 0.280 & $(0.46)$ \\
\hline$\triangle$ Cash Hold $_{t} \times \mathrm{HT} \times$ Boom & 0.102 & $(0.31)$ & 0.507 & $(0.45)$ \\
\hline$\triangle$ Cash Hold $_{t-1} \times \mathrm{HT} \times$ Boom & 0.044 & $(0.30)$ & 0.448 & $(0.42)$ \\
\hline$\triangle$ Cash Hold ${ }_{t} \times \mathrm{HT} \times$ Bust & 0.129 & $(0.51)$ & -0.181 & $(0.87)$ \\
\hline$\triangle$ Cash Hold $_{t-1} \times \mathrm{HT} \times$ Bust & -0.078 & $(0.41)$ & -0.192 & $(0.72)$ \\
\hline$\triangle$ Debt $_{t}$ & $-0.189^{* *}$ & $(0.08)$ & $-0.204^{*}$ & $(0.12)$ \\
\hline$\triangle$ Debt $_{t-1}$ & 0.015 & $(0.09)$ & 0.021 & $(0.13)$ \\
\hline High Tech & $1.068^{* * *}$ & $(0.08)$ & $0.763^{* * *}$ & $(0.11)$ \\
\hline High-Medium Tech & $0.724^{* * *}$ & $(0.05)$ & $0.598^{* * *}$ & $(0.06)$ \\
\hline Low-Medium Tech & $0.276^{* * *}$ & $(0.05)$ & $0.300^{* * *}$ & $(0.06)$ \\
\hline Domestic MNE & 0.044 & $(0.06)$ & -0.065 & $(0.08)$ \\
\hline Foreign MNE & $0.595^{* * *}$ & $(0.05)$ & $0.288^{* * *}$ & $(0.07)$ \\
\hline Independent & $0.588^{* * *}$ & $(0.06)$ & $0.258^{* * *}$ & $(0.08)$ \\
\hline Voung test(p-value) & 0.42 & & 0.12 & \\
\hline sum CashFlow $H T \times$ Bust (p-value) & 0.91 & & 0.86 & \\
\hline sum CashFlow NHT $\times$ Bust (p-value) & 0.01 & & 0.01 & \\
\hline sum $\triangle$ CashHold $H T \times$ Bust (p-value) & 0.94 & & 0.76 & \\
\hline sum $\triangle$ CashHold $N H T \times$ Bust (p-value) & 0.74 & & 0.53 & \\
\hline sum $\triangle$ Debt ( $p$-value $)$ & 0.07 & & 0.33 & \\
\hline Observations & 52,155 & & 20,433 & \\
\hline Uniqe firms & 8,300 & & 2,713 & \\
\hline
\end{tabular}

Robust standard errors in parenthesis

${ }^{*} p<0.1,{ }^{* *} p<0.05,{ }^{* * *} p<0.01$ 


\section{Appendix A: Variable Definition}

Patent $_{t}$ : Total number of patent applications considered at the application date in each year

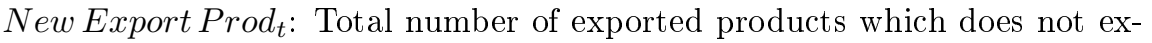
ists before in each period

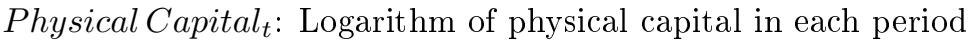

Human Capital $t_{t}$ Human capital measured as share of employees with at least three years of university education

$\triangle$ Sales $_{t}$ : Change in net sales in year $t$ and $t-1$ divided by the beginning of the year $t$ total assets

Size $_{t}: \log$ of total number of employees in each period

Cash Flow ${ }_{t}$ : Cash flow is defined as after tax operating profit plus depreciation and amortization plus investments in plants and equipment divided by the beginning of the year total assets

$\triangle$ Cash Hold $_{t}$ : Change in cash and short-term investments divided by the beginning of the year total assets

$\triangle D e b t_{t}$ : Change in long term debt in year $t$ and $t-1$ divided by the beginning of the year $t$ total assets

Age $_{t}$ : Current year minus the year of creation for each firm in each period

HighTech : High Technology Manufacturing firms based on the OECD NACE classification

High-Medium Tech : Medium-High Technology Manufacturing firms based on the OECD NACE classification

Medium - Low Tech : Medium-low Technology Manufacturing firms based on the OECD NACE classification

Low Tech : Low Technology Manufacturing firms based on the OECD NACE classification

Uni National : Members of a domestic group

Domestic MNE: Members of a domestic multinational group

Foreign MNE: Members of a foreign multinational group

Independent : Non-affiliated firm 
9 Appendix B 


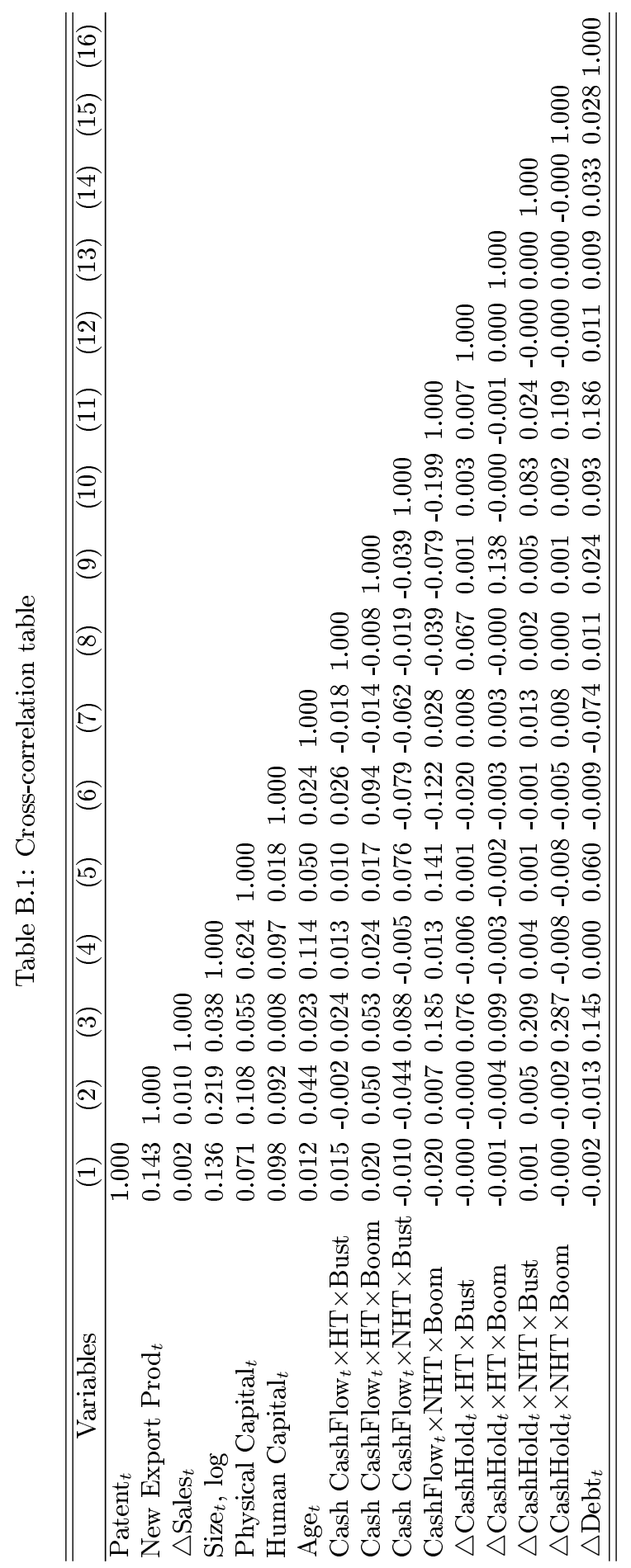

